\title{
Description of Pandoraea gen. nov. with Pandoraea apista sp. nov., Pandoraea pulmonicola sp. nov., Pandoraea pnomenusa sp. nov., Pandoraea sputorum sp. nov. and Pandoraea norimbergensis comb. nov.
}

\author{
Tom Coenye, ${ }^{1}$ Enevold Falsen, ${ }^{2}$ Bart Hoste, ${ }^{3}$ Maria Ohlén, ${ }^{2}$ Johan Goris, ${ }^{1}$ \\ John R. W. Govan, ${ }^{4}$ Monique Gillis ${ }^{1} \&$ Peter Vandamme ${ }^{1}$
}

Author for correspondence: Tom Coenye. Tel: +329264 51 14. Fax: + 3292645092.
e-mail: Tom.Coenye@rug.ac.be

\footnotetext{
1 Laboratorium voor Microbiologie, Universiteit Gent, K. L. Ledeganckstraat 35, B9000 Ghent, Belgium

2 Culture Collection, Department of Clinical Bacteriology, University of Göteborg, Göteborg, Sweden

3 BCCM/LMG Bacteria Collection, Laboratorium voor Microbiologie Gent, Universiteit Gent, Ghent, Belgium

4 Department of Medical Microbiology, University of Edinburgh, Edinburgh, UK
}

\begin{abstract}
A polyphasic taxonomic study was performed on a group of isolates tentatively identified as Burkholderia cepacia, Ralstonia pickettii or Ralstonia paucula (formerly known as CDC group IVc-2). The isolates were mainly cultured from sputum of cystic fibrosis patients or from soil. SDS-PAGE of whole-cell proteins and AFLP fingerprinting distinguished at least five different species, and this was confirmed by DNA-DNA hybridizations. 16S rDNA sequence analysis of representative strains indicated that these organisms belong to the $\beta$-subclass of the Proteobacteria, with the genera Burkholderia and Ralstonia as closest neighbours. Based on genotypic and phenotypic characteristics, the organisms were classified in a novel genus, Pandoraea. The DNA base composition of the members of the new genus is between 61.2 and $64.3 \mathrm{~mol} \%$. This novel genus includes four new species, Pandoraea apista (the type species) (type strain is LMG 16407'), Pandoraea pulmonicola (type strain is LMG 18106'), Pandoraea pnomenusa (type strain is LMG 18087') and Pandoraea sputorum (type strain is LMG 18819'), and Pandoraea norimbergensis (Wittke et al. 1997) comb. nov. (type strain is LMG 18379'). The available clinical data indicate that at least some of these organisms may cause chronic infection in, and can be transmitted amongst, cystic fibrosis patients.
\end{abstract}

Keywords: Pandoraea, Burkholderia, cystic fibrosis, Ralstonia, taxonomy

\section{INTRODUCTION}

The majority of life-threatening bacterial lung infections in cystic fibrosis $(\mathrm{CF})$ patients are caused by a limited spectrum of bacterial pathogens which include Pseudomonas aeruginosa, Staphylococcus aureus and Burkholderia cepacia (Gilligan, 1991; Govan \& Deretic, 1996). Other organisms which can be found regularly in respiratory tract specimens of $\mathrm{CF}$ patients include Haemophilus influenzae, Stenotro-

Abbreviation: $\mathrm{CF}$, cystic fibrosis.

The GenBank accession numbers for the 16S rRNA gene sequences determined in this work are: LMG 18819', AF139176; LMG 13019, AF139171; LMG 18089, AF139172; LMG 16407', AF139173; LMG 18087', AF139174; and LMG 18106' ${ }^{\top}$ AF139175. phomonas maltophilia, certain fungi (e.g. Aspergillus spp.) and viruses (e.g. respiratory syncytial virus) (Gilligan, 1991). In the absence of epidemic spread, $B$. cepacia only infects a small proportion of CF patients, but it has a major impact on both morbidity and mortality of infected patients and the medical and psychosocial implications of B. cepacia colonization and segregation of colonized and non-colonized patients as a means of infection control are enormous (LiPuma, 1998). Accurate identification of B. cepacia is crucial in patient management and infection control practices, but may be problematic, and misidentification is relatively common (LiPuma, 1998).

The present study was initiated by the receipt of several isolates cultured from sputa of $\mathrm{CF}$ patients in 
Denmark, Canada, the USA and Brazil. These strains were tentatively identified as B. cepacia or Ralstonia pickettii-like organisms or as Ralstonia paucula (formerly known as Centers for Disease Control group IVc-2; Vandamme et al., 1999). This report describes the polyphasic taxonomic study which was used for the characterization of these and similar isolates from the environment and human clinical specimens. The genotypic and phenotypic characteristics warranted the classification of the isolates in a novel genus, for which we propose the name Pandoraea. The genus Pandoraea contains five species: Pandoraea apista sp. nov. (the type species), Pandoraea pulmonicola sp. nov., Pandoraea pnomenusa sp. nov., Pandoraea sputorum sp. nov. and Pandoraea norimbergensis (Wittke et al. 1997) comb. nov. (basonym Burkholderia norimbergensis). The name Burkholderia norimbergensis was proposed by Wittke et al. (1997) for a single bacterial isolate capable of hetrotrophic sulfur oxidation, which was isolated from an oxic water layer above a sulfide-containing sediment.

\section{METHODS}

Bacterial strains and growth conditions. Strains used in this study are listed in Table 1. All strains were grown aerobically on Trypticase Soy Agar (BBL) at $37^{\circ} \mathrm{C}$ unless otherwise indicated.

Phenotypic characterization. Classical phenotypic tests were performed as described previously (Vandamme et al., 1993). API ZYM and API20 NE tests were performed according to the recommendations of the manufacturer (bioMérieux). Flagella staining was performed using a solution of tannic acid $(2 \mathrm{~g}) / \operatorname{phenol}(5 \%, \mathrm{w} / \mathrm{v}) / \mathrm{KAl}_{(}\left(\mathrm{SO}_{4}\right)_{2}$ (saturated) in $11 \mathrm{ml}$ saturated crystal violet in $95 \%$ ethanol. Stained cells were viewed by phase-contrast microscopy.

Phytopathogenicity was tested as described by Gonzalez \& Vidaver (1979). In brief, strains were grown for $24 \mathrm{~h}$ at $28^{\circ} \mathrm{C}$. Bacterial suspensions containing $10^{9} \mathrm{c}$.f.u. $\mathrm{ml}^{-1}$ were prepared in sterile distilled water and $100 \mu \mathrm{l}$ of the suspension was inoculated on $3-5 \mathrm{~mm}$ thick onion slices. The inoculated slices were incubated for $48 \mathrm{~h}$ at $28^{\circ} \mathrm{C}$ in moist chambers. B. cepacia genomovar I strain LMG $1222^{\mathrm{T}}$ was used as a positive control. Sterile distilled water was used as a negative control.

Growth on B. cepacia-selective agar (DM253; Mast Diagnostics) containing ticarcillin $\left(100 \mathrm{mg}^{-1}\right)$ and polymyxin $\mathrm{B}$ $\left(300000 \mathrm{U}^{-1}\right)$ was tested by incubating the strains at $37^{\circ} \mathrm{C}$ for 48 h. B. cepacia genomovar III LMG 16656 was used as a positive control.

Degradation of poly-3-hydroxybutyrate (PHB) was tested by growing the strains on minimal Delafield medium containing $0.005 \%(\mathrm{w} / \mathrm{v})$ yeast extract, $0 \cdot 1 \%(\mathrm{w} / \mathrm{v}) \mathrm{NH}_{4} \mathrm{Cl}$, $0.05 \%(\mathrm{w} / \mathrm{v}) \mathrm{MgSO}_{4} .7 \mathrm{H}_{2} \mathrm{O}, 0.005 \%$ (w/v) ferric ammonium citrate and $2.0 \%(\mathrm{w} / \mathrm{v})$ agar in $0.033 \mathrm{M} \mathrm{KH}_{2} \mathrm{PO}_{4} / \mathrm{Na}_{2} \mathrm{HPO}_{4}$ buffer $\mathrm{pH} 6.8$ and covering with a layer of $\mathrm{PHB}$ agar containing $2.5 \%(\mathrm{w} / \mathrm{v}) \mathrm{PHB}$ and $2.0 \%$ agar. Strains were incubated at $37^{\circ} \mathrm{C}$ for $7 \mathrm{~d}$. Acidovorax facilis PHA 774 and Pseudomonas balearica PHA 785 were used as positive controls. Degradation of PHB was recognized by the appearance of clear haloes surrounding the colonies.
SDSPAGE of whole-cell proteins. Strains were grown on nutrient agar containing $0.1 \%(\mathrm{w} / \mathrm{v})$ beef extract, $0 \cdot 2 \%$ $(\mathrm{w} / \mathrm{v})$ yeast extract, $0.5 \%(\mathrm{w} / \mathrm{v}) \mathrm{NaCl}, 0.5 \%(\mathrm{w} / \mathrm{v})$ peptone, $0.04 \%(\mathrm{w} / \mathrm{v}) \mathrm{KH}_{2} \mathrm{PO}_{4}, 0.24 \%(\mathrm{w} / \mathrm{v}) \mathrm{Na}_{2} \mathrm{HPO}_{4} .12 \mathrm{H}_{2} \mathrm{O}$ and $2.0 \%$ agar $(\mathrm{pH} 6.8)$ for $48 \mathrm{~h}$ at $28{ }^{\circ} \mathrm{C}$. Preparation of wholecell proteins and SDS-PAGE were performed as described previously (Pot et al., 1994). Densitometric analysis, normalization and interpolation of the protein profiles, and numerical analysis using the Pearson product moment correlation coefficient were performed using the GelCompar 4.2 software package (Applied Maths).

DNA preparation. This was done as described by Pitcher et al. (1989).

AFLP fingerprinting. The preparation of template DNA (using restriction enzymes $A p a \mathrm{I}$ and $T a q \mathrm{I}$ ), amplification [using primers A00 and T00 in the preselective PCR and primers B07 (labelled with the fluorescent dye 6-FAM) and T11 in the selective PCR], separation of the fragments using an ABI Prism 377 automated DNA sequencer and numerical analysis were performed as described previously (Coenye $e t$ al., 1999b).

$16 S$ rDNA sequencing. The nearly complete (corresponding to positions 8-1541 in the Escherichia coli numbering system) 16S rRNA gene of strains LMG $18819^{\mathrm{T}}$, LMG $18087^{\mathrm{T}}$, LMG 13019, LMG 18106 ${ }^{\mathrm{T}}$, LMG 18089 and LMG $16407^{\mathrm{T}}$ was amplified by PCR using conserved primers [5'-AGAGTTTGATCCTGGCTCAG-3' (5'-CTGGCTCAGGAC/ TGAACGCTG-3' for LMG $18087^{\mathrm{T}}$ ) and $5^{\prime}$-AAGGAGGTGATCCAGCCGCA-3']. The PCR products were purified using a QIAquick PCR Purification kit (Qiagen) according to the manufacturer's instructions. Sequence analysis was performed using an Applied Biosystems 377 DNA Sequencer and the protocols of the manufacturer (PerkinElmer Applied Biosystems) using the ABI Prism Dye or BigDye Terminator Cycle Sequencing Ready Reaction kit. The sequencing primers were those described by Coenye et al. (1999a) except that primer * $\mathrm{R}$ was replaced by $* \mathrm{R} 2\left(5^{\prime}-\right.$ GCTACACACTGCTACAATG-3'). Sequence assembly was performed by using the program AutoAssembler 1.4.0 (Perkin-Elmer Applied Biosystems). Phylogenetic analysis was performed using the GeneCompar 2.1 software package (Applied Maths). A phylogenetic tree was constructed based on the neighbour-joining method (Saitou \& Nei, 1987).

Determination of the DNA base composition. DNA was enzymically degraded into nucleosides as described by Mesbah et al. (1989). The obtained nucleoside mixture was then separated by HPLC using a Waters SymmetryShield C8 column thermostated at $37{ }^{\circ} \mathrm{C}$. The solvent was $0.02 \mathrm{M}$ $\mathrm{NH}_{4} \mathrm{H}_{2} \mathrm{PO}_{4} \mathrm{pH} 4.0$ with $1.5 \%$ acetonitrile. Non-methylated lambda phage DNA (Sigma) was used as the calibration reference.

DNA-DNA hybridizations. These were performed with photobiotin-labelled probes in microplate wells as described by Ezaki et al. (1989), using an HTS7000 Bio Assay Reader (Perkin-Elmer) for the fluorescence measurements. The hybridization temperature was $50^{\circ} \mathrm{C}$. Reciprocal experiments were performed for every pair of strains and each value given is the mean of at least two hybridization experiments. The variation between reciprocal reactions and repeated experiments is around $7 \%$ with this method (Goris et al., 1998).

Fatty acid methyl ester analysis. After an incubation period of $24 \mathrm{~h}$ at $35^{\circ} \mathrm{C}$, a loopful of well-grown cells was harvested 
Table 1. List of strains studied

CCUG, Culture Collection, University of Göteborg, Department of Clinical Bacteriology, Göteborg, Sweden; DSM, Deutsche Sammlung von Mikroorganismen und Zellkulturen GmbH, Braunschweig, Germany; LMG, BCCM/LMG Bacteria Collection Laboratorium voor Microbiologie Gent, Universiteit Gent, Belgium; NCTC, National Collection of Type Cultures, London, UK.

\begin{tabular}{|c|c|c|c|}
\hline $\begin{array}{l}\text { Species and strain } \\
\text { designation }\end{array}$ & $\begin{array}{c}\text { Other strain } \\
\text { designations }\end{array}$ & Depositor & Source \\
\hline $\begin{array}{l}\text { Burkholderia cepacia } \\
\text { genomovar I } \\
\text { LMG } 1222^{\mathrm{T}}\end{array}$ & NCTC $10743^{T}$ & B. Contopoulos & Allium сера \\
\hline $\begin{array}{l}\text { Burkholderia cepacia } \\
\text { genomovar III } \\
\text { LMG } 16656\end{array}$ & $\mathrm{~J} 2315$ & Own isolate & CF patient (UK, 1989) \\
\hline $\begin{array}{l}\text { Burkholderia cepacia } \\
\text { genomovar IV } \\
\text { LMG } 13017\end{array}$ & & S. Lauwers & Blood culture (Belgium, 1988) \\
\hline $\begin{array}{l}\text { Burkholderia multivorans } \\
\text { LMG } 13010^{\mathrm{T}}\end{array}$ & NCTC $13007^{T}$ & S. Lauwers & CF patient (Belgium, 1992) \\
\hline $\begin{array}{l}\text { Burkholderia vietnamiensis } \\
\mathrm{LMG} 10929^{\mathrm{T}}\end{array}$ & TVV $75^{\mathrm{T}}$ & T. Heulin & Rice rhizosphere (Vietnam) \\
\hline $\begin{array}{l}\text { Pandoraea norimbergensis } \\
\text { LMG } 18379^{\mathrm{T}}\end{array}$ & $\begin{array}{l}\text { CCUG } 39188^{\mathrm{T}} \\
\text { DSM } 11628^{\mathrm{T}}\end{array}$ & DSM & $\begin{array}{l}\text { Oxic water layer above a sulfide-containing } \\
\text { sediment (Nürnberg, Germany) }\end{array}$ \\
\hline LMG 13019 & CCUG 38411 & S. Lauwers & Blood culture (Belgium, 1990) \\
\hline LMG 16603 & CCUG 34867 & Own isolate & Human broncheal alveolar lavage (Sweden) \\
\hline $\mathrm{R}-4026$ & CCUG 39677 & J. Moore & Powdered milk \\
\hline $\begin{array}{l}\text { Pandoraea pulmonicola } \\
\text { LMG } 18106^{\mathrm{T}} \\
\text { LMG } 18107 \\
\text { LMG } 18108\end{array}$ & $\begin{array}{l}\text { CCUG } 38759^{\mathrm{T}} \\
\text { CCUG } 38779 \\
\text { CCUG } 38745\end{array}$ & $\begin{array}{l}\text { D. Speert } \\
\text { J. LiPuma } \\
\text { J. LiPuma }\end{array}$ & $\begin{array}{l}\text { CF patient (Canada) } \\
\text { CF patient (USA) } \\
\text { CF patient (USA) }\end{array}$ \\
\hline $\begin{array}{l}\text { Pandoraea pnomenusa } \\
\text { LMG } 18087^{\mathrm{T}} \\
\text { LMG } 18820 \\
\text { R-1454 } \\
\text { LMG } 18817 \\
\text { R-4805 } \\
\text { R-5620 }\end{array}$ & $\begin{array}{l}\text { CCUG } 38742^{\mathrm{T}} \\
\text { CCUG } 39683 \\
\text { CCUG } 39672 \\
\text { CCUG } 39689 \\
\text { CCUG } 39694 \\
355\end{array}$ & $\begin{array}{l}\text { Own isolate } \\
\text { J. Mergaert } \\
\text { D. Speert } \\
\text { J. LiPuma } \\
\text { J. LiPuma } \\
\text { S. Canani }\end{array}$ & $\begin{array}{l}\text { CF patient (UK) } \\
\text { Sludge (Germany) } \\
\text { CF patient (Canada, 1996) } \\
\text { CF patient (USA) } \\
\text { CF patient (USA) } \\
\text { CF patient (Brazil, 1997) }\end{array}$ \\
\hline $\begin{array}{l}\text { Pandoraea apista } \\
\text { LMG } 16407^{\mathrm{T}} \\
\text { LMG } 16408 \\
\text { LMG } 16409 \\
\text { LMG } 16410 \\
\text { LMG } 16411 \\
\text { LMG } 18089 \\
\text { R-2394 } \\
\text { R-2395 } \\
\text { R-2441 } \\
\text { R-2885 } \\
\text { R-3202 } \\
\text { LMG } 18818 \\
\text { R-4520 } \\
\text { R-4527 } \\
\text { R-4529 } \\
\text { R-6145 }\end{array}$ & $\begin{array}{l}\text { CCUG } 38412^{\mathrm{T}} \\
\text { CCUG } 38413 \\
13037 \\
13038 \\
13720 \\
\text { CCUG } 38750 \\
\text { CCUG } 39675 \\
\text { CCUG } 39674 \\
\text { CCUG } 39679 \\
\text { CCUG } 39681 \\
\text { CCUG } 39676 \\
\text { CCUG } 39687 \\
\text { CCUG } 39688 \\
\text { CCUG } 39690 \\
\text { CCUG } 39686 \\
\text { AU0786 }\end{array}$ & $\begin{array}{l}\text { N. Høiby } \\
\text { N. Høiby } \\
\text { N. Høiby } \\
\text { N. Høiby } \\
\text { N. Høiby } \\
\text { D. Speert } \\
\text { J. LiPuma } \\
\text { J. LiPuma } \\
\text { J. LiPuma } \\
\text { J. LiPuma } \\
\text { J. LiPuma } \\
\text { J. LiPuma } \\
\text { J. LiPuma } \\
\text { J. LiPuma } \\
\text { J. LiPuma } \\
\text { J. LiPuma }\end{array}$ & $\begin{array}{l}\text { CF patient (Denmark) } \\
\text { CF patient (Denmark) } \\
\text { CF patient (Denmark) } \\
\text { CF patient (Denmark) } \\
\text { CF patient (Denmark) } \\
\text { CF patient (USA) } \\
\text { CF patient (USA) } \\
\text { CF patient (USA) } \\
\text { CF patient (USA) } \\
\text { CF patient (USA) } \\
\text { CF patient (USA) } \\
\text { CF patient (USA) } \\
\text { CF patient (USA) } \\
\text { CF patient (USA) } \\
\text { CF patient (USA) } \\
\text { CF patient (USA) }\end{array}$ \\
\hline $\begin{array}{l}\text { Pandoraea sputorum } \\
\text { LMG } 18819^{\mathrm{T}} \\
\text { LMG } 18100 \\
\text { R-2456 } \\
\text { R-2711 } \\
\text { R-2886 } \\
\text { R-2398 } \\
\text { R-3080 }\end{array}$ & $\begin{array}{l}\text { CCUG } 39682^{\mathrm{T}} \\
\text { CCUG } 38753 \\
\text { CCUG } 39685 \\
\text { CCUG } 39691 \\
\text { CCUG } 39684 \\
\text { CCUG } 39673 \\
\text { CCUG } 39693\end{array}$ & $\begin{array}{l} \\
\text { J. LiPuma } \\
\text { D. Speert } \\
\text { J. LiPuma } \\
\text { D. Speert } \\
\text { J. LiPuma } \\
\text { J. LiPuma } \\
\text { J. LiPuma }\end{array}$ & $\begin{array}{l}\text { CF patient (USA) } \\
\text { CF patient (Canada, 1992) } \\
\text { CF patient (USA) } \\
\text { CF patient (USA, 1997) } \\
\text { CF patient (USA) } \\
\text { CF patient (USA) } \\
\text { CF patient (USA) }\end{array}$ \\
\hline $\begin{array}{l}\text { Pandoraea sp. } \\
\text { R-5199 }\end{array}$ & CCUG 39680, JB1 & M. Mergeay & Garden soil \\
\hline $\begin{array}{l}\text { Ralstonia pickettii } \\
\text { LMG } 5942^{\mathrm{T}}\end{array}$ & CCUG $3318^{\mathrm{T}}$ & M. Pickett & Patient after tracheotomy (USA) \\
\hline $\begin{array}{l}\text { Ralstonia paucula } \\
\text { LMG } 3244^{\mathrm{T}}\end{array}$ & CCUG $12507^{\mathrm{T}}$ & R. Weaver & Human respiratory tract (USA) \\
\hline
\end{tabular}


and fatty acid methyl esters were prepared, separated and identified using the Microbial Identification System (Microbial ID) as described previously (Vandamme et al., 1992).

\section{RESULTS}

\section{Phenotypic characterization}

The following characteristics were present in all of the Pandoraea strains investigated: catalase activity; growth at 30 and $37^{\circ} \mathrm{C}$; growth on Drigalsky agar; growth in 0.5 and $1.5 \% \mathrm{NaCl}$; assimilation of $\mathrm{D}-$ gluconate, L-malate and phenylacetate; acid and alkaline phosphatase and leucine arylamidase activity. The following features were absent in all the Pandoraea strains investigated: growth in $6.0 \% \mathrm{NaCl}$ and $10 \%$ lactose; hydrolysis of Tween 80 and aesculin; nitrite reduction; denitrification; gelatin liquefaction; growth in $\mathrm{O} / \mathrm{F}$ medium with adonitol, fructose and xylose; indole production; production of acid or $\mathrm{H}_{2} \mathrm{~S}$ from TSI agar; assimilation of trehalose, L-arginine, DLnorleucine, L-arabinose, D-mannose, D-mannitol and $N$-acetylglucosamine; DNase, ornithine decarboxylase, lysine decarboxylase, tryptophanase, $\mathrm{C}_{14}$-lipase, valine arylamidase, trypsin, chymotrypsin, $\alpha$ galactosidase, $\beta$-galactosidase, $\beta$-glucuronidase, $\alpha$-glucosidase, $\beta$-glucosidase, $N$-acetyl- $\beta$-glucosaminidase, $\alpha$-mannosidase and $\alpha$-fucosidase activity. Other features were taxon- or strain-dependent and are shown in Table 2.

None of the isolates tested was able to cause soft rot on onions under the conditions used. All isolates investigated grew on $B$. cepacia-selective medium, except strain R-5199, which showed no growth even after prolonged incubation $(96 \mathrm{~h})$. None of the strains was able to degrade PHB under the conditions used.

\section{SDSPAGE of whole-cell proteins}

Reproducibility was checked by preparing protein extracts in duplicate. The correlation level between these patterns was more than 93\% (data not shown). After numerical analysis and visual comparison of the profiles, six clusters could be delineated above a correlation level of $85 \%$ (Fig. 1). Cluster A was

Table 2. Differential biochemical characteristics

Results are expressed as the percentage of strains investigated that gave a positive reaction; $(+)$ or $(-)$ indicates positive or negative reaction of type strain.

\begin{tabular}{|c|c|c|c|c|c|c|}
\hline Character & $\begin{array}{l}P . \text { norimbergensis } \\
(n=4)\end{array}$ & $\begin{array}{c}P \cdot \text { pulmonicola } \\
(n=3)\end{array}$ & $\begin{array}{c}P . \text { pnomenusa } \\
(n=6)\end{array}$ & $\begin{array}{r}P . \text { apista } \\
(n=11)\end{array}$ & $\begin{array}{c}P . \text { sputorum } \\
(n=7)\end{array}$ & $\begin{array}{l}\text { Pandoraea sp. } \\
\text { R-5199 }(n=1)\end{array}$ \\
\hline Growth at $42{ }^{\circ} \mathrm{C}$ & 0 & 100 & 100 & 100 & $57(+)$ & 0 \\
\hline \multicolumn{7}{|l|}{ Growth on: } \\
\hline Acetamide & 0 & 0 & $16(-)$ & 0 & 0 & 0 \\
\hline Cetrimide agar & 100 & 100 & $66(-)$ & 100 & $62(+)$ & 0 \\
\hline $\begin{array}{l}\text { Growth in } \mathrm{O} / \mathrm{F} \text { medium } \\
\text { with } \mathrm{D} \text {-glucose }\end{array}$ & $25(+)$ & 100 & 0 & 0 & 0 & 0 \\
\hline Nitrate reduction & 0 & 0 & $83(+)$ & 0 & $14(+)$ & 100 \\
\hline \multicolumn{7}{|l|}{ Growth in: } \\
\hline $3.0 \% \mathrm{NaCl}$ & $25(-)$ & 0 & 100 & $82(-)$ & $57(+)$ & 0 \\
\hline $4.5 \% \mathrm{NaCl}$ & 0 & 0 & $50(-)$ & $9(-)$ & 0 & 0 \\
\hline \multicolumn{7}{|l|}{ Assimilation of: } \\
\hline Caprate & $75(-)$ & 100 & 100 & $82(-)$ & $62(-)$ & 0 \\
\hline Adipate & 0 & 0 & $16(-)$ & $55(-)$ & $62(+)$ & 0 \\
\hline DL-Lactate & $75(+)$ & 100 & 100 & 100 & $29(+)$ & 100 \\
\hline $\begin{array}{l}\text { Mannose, mannitol, } \\
\text { maltose, } N \text { - } \\
\text { acetylglucosamine }\end{array}$ & $25(-)$ & 0 & 0 & 0 & 0 & 0 \\
\hline Urease activity & $75(-)$ & 0 & 100 & 100 & $14(-)$ & 100 \\
\hline Oxidase activity & 100 & 100 & $33(-)$ & $64(-)$ & $57(+)$ & 0 \\
\hline $\mathrm{C}_{4}$-esterase activity & $66(+)^{*}$ & 0 & $84(-)$ & $82(+)$ & $85(+)$ & 100 \\
\hline $\mathrm{C}_{8}$-ester-lipase activity & $100^{*}$ & 0 & 100 & 100 & 100 & 100 \\
\hline $\begin{array}{l}\text { Cysteine arylamidase } \\
\text { activity }\end{array}$ & $0 *$ & 0 & $16(+)$ & $9(-)$ & $14(-)$ & 0 \\
\hline $\begin{array}{l}\text { Phosphoamidase } \\
\text { activity }\end{array}$ & $100^{*}$ & 100 & $84(+)$ & 100 & 100 & 100 \\
\hline
\end{tabular}

$* n=3$. 


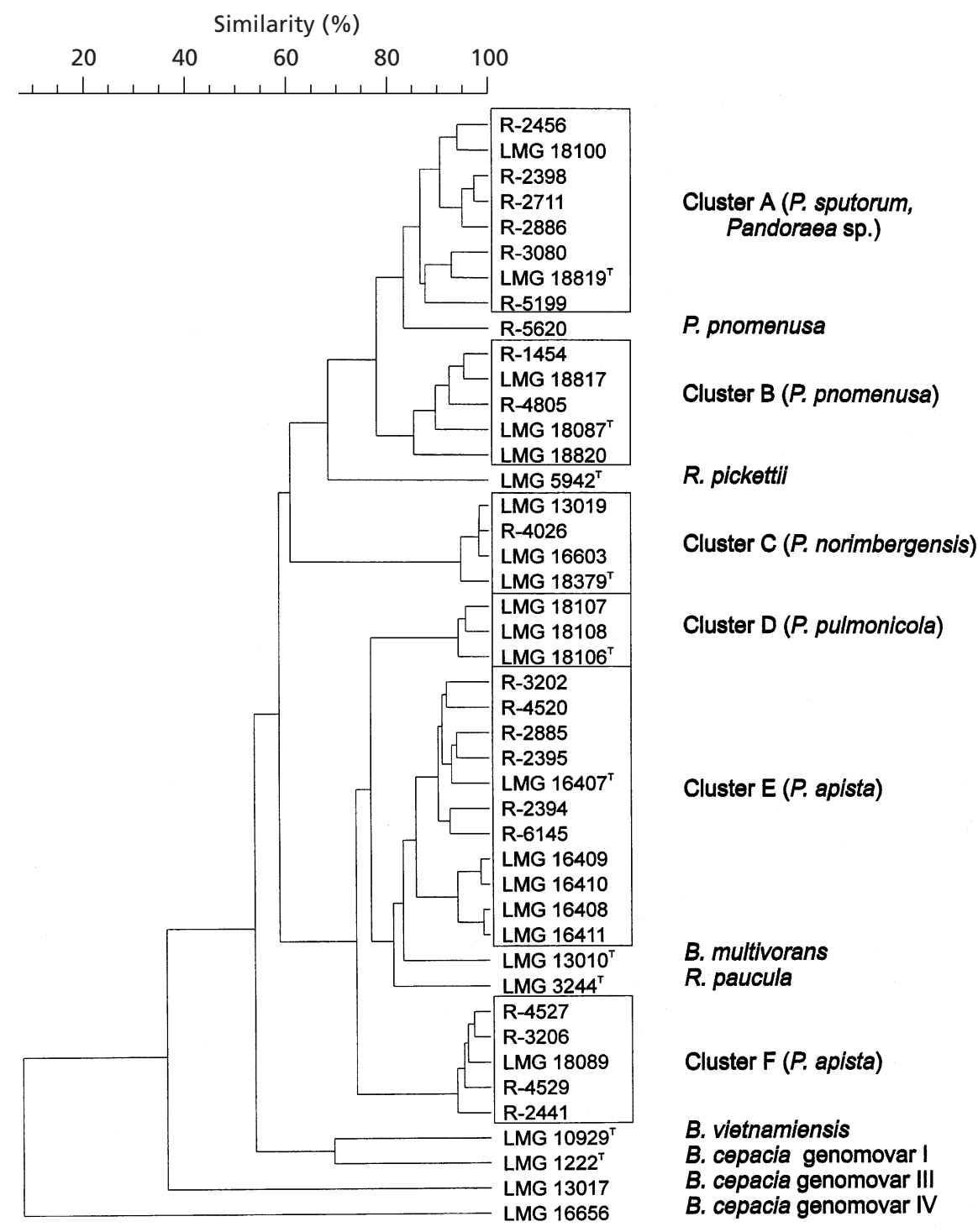

Fig. 1. Dendrogram derived from the unweighted pair group average linkage of correlation coefficients between the protein patterns of the strains studied. The correlation coefficient is expressed as percentage similarity for convenience.

composed of eight strains. Cluster B comprised five strains. B. norimbergensis LMG $18379^{\mathrm{T}}$ and three other strains (LMG 13019, R-4026 and LMG 16603) constituted cluster $\mathrm{C}$. Three strains formed cluster D. Clusters $\mathrm{E}$ and $\mathrm{F}$ contained 11 and 5 strains, respectively. Finally, strain R-5620 and reference strains of members of the B. cepacia complex, R. pickettii and $R$. paucula occupied separate positions in the dendrogram. A selection of protein patterns of representative strains from each cluster is shown in Fig. 2. Visual comparison of the protein patterns indicated that strain R-5620 belongs to cluster B. However, in the numerical analysis of the protein patterns R-5620 occupies a separate position. This is due to significant and reproducible distortions of its protein pattern (Fig. 2), which can have a profound effect on numerical analysis as discussed previously (Vandamme et al., 1997). The same is true for strain R-5199, which groups in cluster A but has a significantly different protein pattern.

\section{AFLP fingerprinting}

Reproducibility was checked by preparing PCR products in duplicate and the similarity between patterns obtained with two PCR products was always higher than $92 \%$. Following numerical analysis, five clusters could be delineated, whilst several strains occupied a separate position (Fig. 3). Cluster I comprised the type strain of $P$. norimbergensis and strains LMG 13019, R-4026 and LMG 16603. Clusters II, III, IV and V were composed of $6,11,6$ and 3 strains, respectively. Reference strains of members of the $B$. cepacia complex, R. pickettii and R. paucula, and strain R-5199 occupied separate positions in the dendrogram. 


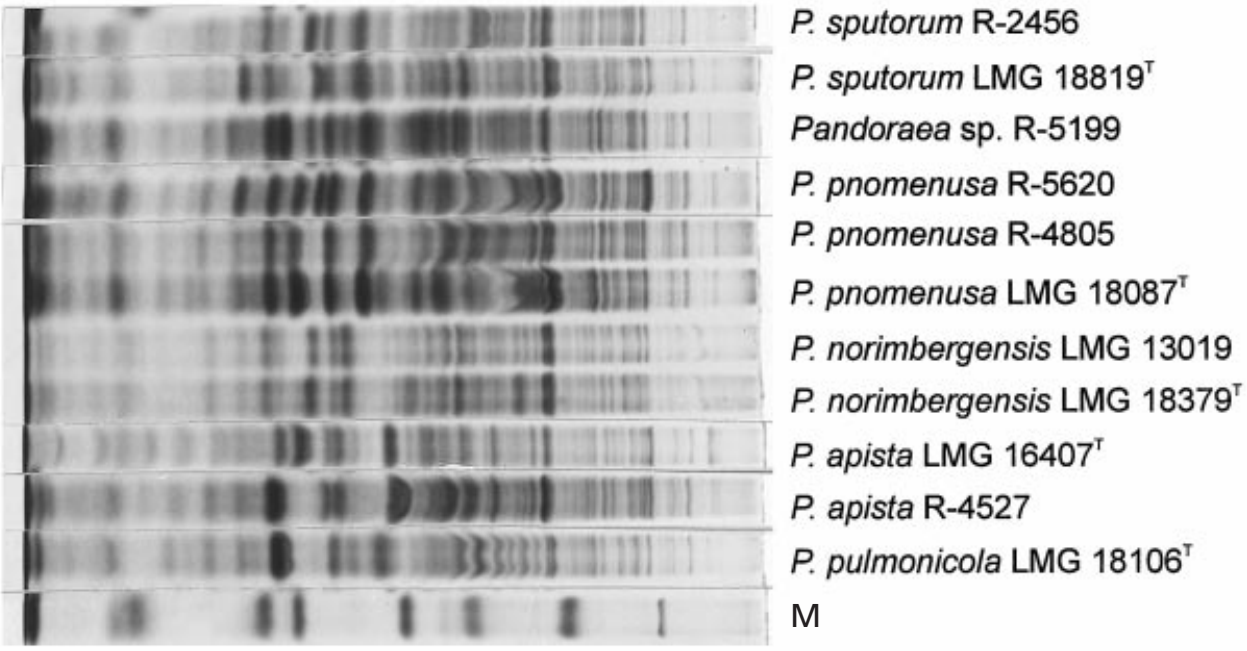

Fig. 2. Electrophoretic protein patterns of a selection of the strains investigated. The molecular mass markers used (lane M) were (from left to right) lysozyme $(14.5 \mathrm{kDa})$, trypsin inhibitor $(20 \mathrm{kDa})$, trypsinogen $(24 \mathrm{kDa})$, glyceraldehyde-3phosphate dehydrogenase (36 kDa), egg albumin (45 kDa), bovine albumin (60 kDa) and $\beta$-galactosidase (116 kDa).

\section{S rRNA gene sequencing}

The 16S rRNA sequences of representative strains of the protein electrophoretic and/or AFLP clusters were determined and compared with available 16S rRNA sequences of $B$. norimbergensis LMG $18379^{\mathrm{T}}$ and strain $\mathrm{R}-5199$ and other representatives of the $\beta$-Proteobacteria. All 16S rRNA gene sequences determined in the present study were closely related to the sequence of $B$. norimbergensis LMG $18379^{\mathrm{T}}$ and strain R-5199 (Fig. 4), forming a homogeneous cluster with internal 16S rRNA gene sequence similarities above $96 \%$. Similarity levels towards other taxa belonging to the $\beta$-Proteobacteria were below $95 \cdot 3 \%$.

\section{DNA-DNA hybridizations and determination of $\mathbf{G}+\mathbf{C}$ content}

DNA was prepared from strains representing each protein electrophoretic cluster. The DNA-DNA binding values and the $\mathrm{G}+\mathrm{C}$ content of all strains examined are shown in Table 3 . All strains investigated had $\mathrm{G}+\mathrm{C}$ contents between 61.2 and $64.3 \mathrm{~mol} \%$. The hybridization results revealed that there were five groups with internal DNA-DNA binding values higher than $88 \%$. DNA-DNA binding values between representatives of the different groups were between 32 and $45 \%$.

\section{Cellular fatty acid analysis}

Both quantitative and qualitative differences in cellular fatty acid composition occur between the different Pandoraea species (Table 4). The predominant fatty acids in all strains investigated were 16:0, 17:0 cyclo, 16:0 3-OH, 19:0 cyclo $\omega 8 c$, summed feature 3 (comprising 14:0 3-OH, 16:1 iso $\mathrm{I}$, an unidentified fatty acid with equivalent chain length of 10.928 , or $12: 0$
ALDE, or any combination of these fatty acids), summed feature 4 (comprising 16:1 $\omega 7 c$ or 15 iso 2$\mathrm{OH}$ or both) and summed feature 7 (comprising 18:1 $\omega 7 c, 18: 1 \omega 9 t$, or $18: 1 \omega 12 t$, or any combination of these fatty acids).

\section{DISCUSSION}

We investigated a set of strains, primarily isolated from sputa of CF patients and the environment, which proved difficult to identify in routine diagnostic laboratories. These strains were tentatively grouped by SDS-PAGE of whole-cell proteins and AFLP fingerprinting, and a polyphasic taxonomic approach (including $16 \mathrm{~S}$ rDNA sequencing, DNA-DNA hybridization, cellular fatty acid analysis and extensive biochemical characterization) was used to clarify their relationships and to determine their phylogenetic position.

\section{Phylogenetic position and structure of the genus Pandoraea}

Representative strains of the different protein electrophoretic and AFLP clusters (LMG 13019, LMG 18089, LMG $16407^{\mathrm{T}}, \mathrm{LMG} 18087^{\mathrm{T}}$ and LMG $18106^{\mathrm{T}}$ ) formed a single phylogenetic lineage together with $B$. norimbergensis LMG $18379^{\mathrm{T}}$ and strain R-5199, with internal similarity levels being higher than $96.0 \%$ (Fig. 4). The closest related genera are Burkholderia and Ralstonia, but similarities towards the type species of these genera ( $B$. cepacia and $R$. pickettii) are below $93 \cdot 2 \%$ and $92 \cdot 1 \%$, respectively. Bootstrap analysis indicates that these strains represent a stable clade of species with a phylogenetic position intermediate between the genera Burkholderia and Ralstonia. The stability of the cluster and the low similarity levels 


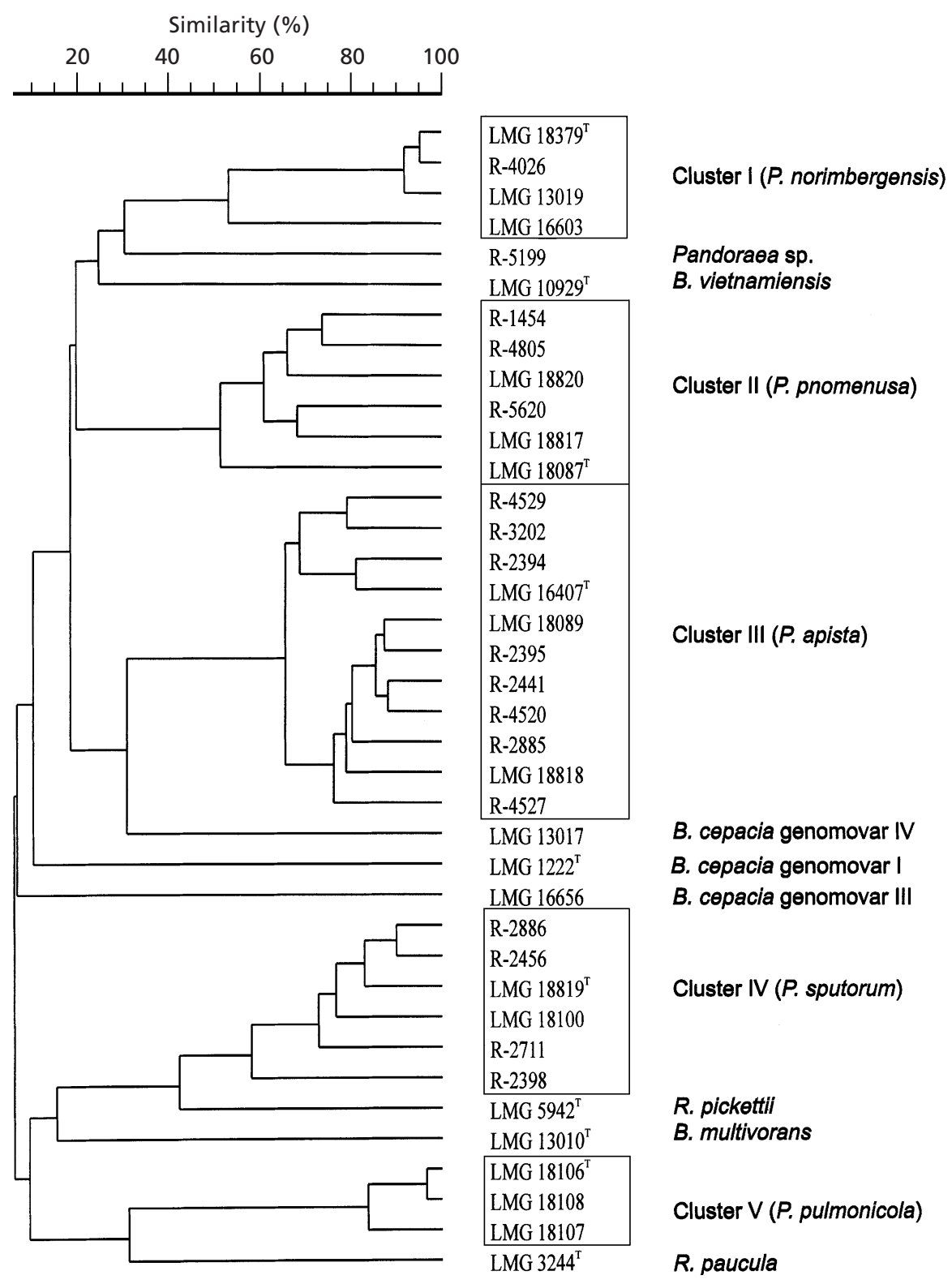

Fig. 3. Dendrogram derived from the unweighted pair group average linkage of correlation coefficients between the AFLP patterns of the strains studied. The correlation coefficient is expressed as percentage similarity for convenience.

towards the type species of the closest related genera led to the conclusion that these strains represent a novel genus, for which we propose the name Pandoraea. Since the type strain of $B$. norimbergensis belongs to this cluster, this species should be transferred to the new genus as Pandoraea norimbergensis (Wittke et al. 1997) comb. nov.

The dendrograms shown in Figs 1 and 3 suggested that at least five different genomic groups were present within the new genus. Since the similarity levels between the respective rRNA genes of strains belonging to the different clusters were higher than $97 \%$, DNA-DNA hybridizations were performed to determine their exact degree of genetic relatedness (Stackebrandt \& Goebel, 1994). Strains representing all of the AFLP clusters were included in DNA-DNA hybridizations. The results suggested that each AFLP cluster forms one single species. The results also suggested that strains belonging to protein electrophoretic clusters A (except for R-5199), B, C and D form one single species each. Strains LMG $16407^{\mathrm{T}}$ (cluster E) and R-4527 (cluster F) exhibit high DNA-DNA binding (94\%) (as could be expected from the AFLP results: both strains group in cluster III) and can therefore be considered as two electrophoretic types of a single species (Costas, 1992). We conclude that strains from each AFLP cluster con- 


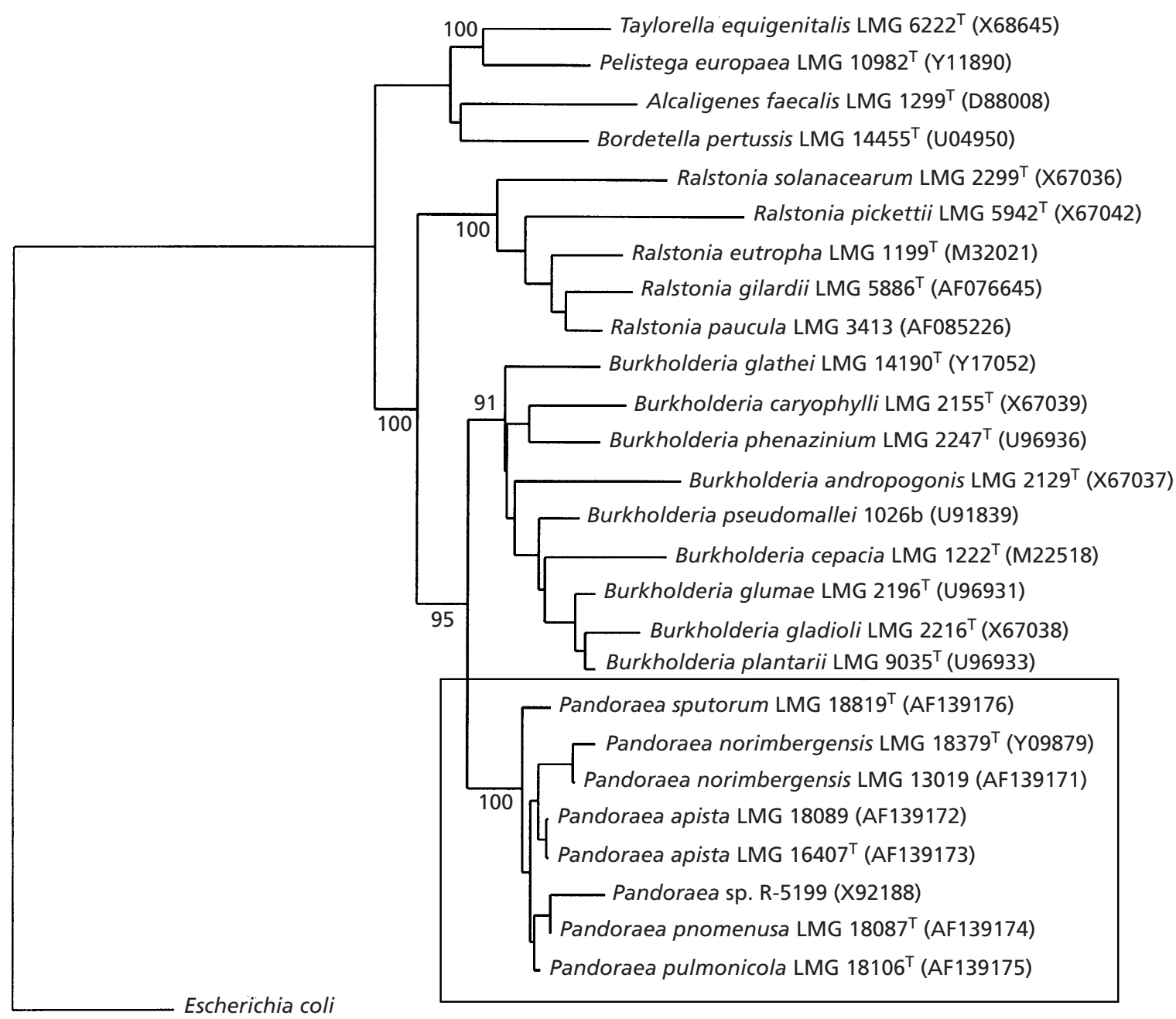

Fig. 4. Distance matrix tree showing the phylogenetic position of the genus Pandoraea (boxed) within the $\beta$ Proteobacteria based on $16 \mathrm{~S}$ rDNA sequence comparisons. E. coli was used as an outgroup in this analysis. The scale bar indicates $10 \%$ sequence dissimilarity.

stitute a single species: $P$. norimbergensis (AFLP cluster I), P. pnomenusa (cluster II), P. apista (cluster III), $P$. sputorum (cluster IV) and $P$. pulmonicola (cluster V). Strain R-5199 occupies a separate position and probably does not belong to any of the described Pandoraea species.

\section{Differentiation and identification of Pandoraea species}

Several biochemical characters are useful to differentiate Pandoraea species (Table 2). The most important are growth at $42{ }^{\circ} \mathrm{C}$, growth in $\mathrm{O} / \mathrm{F}$ medium with $\mathrm{D}-$ glucose, growth in $3 \% \mathrm{NaCl}$, nitrate reduction and urease, oxidase, $\mathrm{C}_{4}$-esterase and $\mathrm{C}_{8}$-ester-lipase activity.

Both quantitative and qualitative differences occur in the fatty acid composition of the different Pandoraea species (see Table 4). In particular, the relative amounts of summed feature 7 and 19:0 cyclo $\omega 8 c$ vary strongly amongst species. $P$. pnomenusa and $P$. apista can be differentiated from $P$. norimbergensis, $P$. pulmonicola and $P$. sputorum by the presence of significant amounts of 18:12-OH. In general however, these differences are small and it seems questionable if they will suffice to identify strains to the species level.

Figs 1 and 2 show that different Pandoraea species are characterized by different whole-cell protein profiles. However, the presence of distortions in the patterns, similar to the reported distortions in Burkholderia and Ralstonia strains (Vandamme et al., 1997; Coenye et al., 1999a; Vandamme et al., 1999), hinder identification of strains based solely on numerical analysis, and strains occasionally may occupy misleading positions in the dendrogram (cf. the position of strain $P$. pnomenusa R-5620). Therefore visual comparison 
Table 3. DNA-DNA binding values and $\mathrm{G}+\mathrm{C}$ content of all strains examined

Mean standard deviation of DNA-DNA hybridization values is approximately $7 \%$ (Goris et al., 1998).

\begin{tabular}{|c|c|c|c|c|c|c|c|c|c|c|}
\hline \multirow[t]{2}{*}{ Strain } & \multirow{2}{*}{$\begin{array}{c}\mathrm{G}+\mathrm{C} \\
\text { content } \\
(\mathrm{mol} \%)\end{array}$} & \multicolumn{9}{|c|}{ DNA-binding value (\%) with strain: } \\
\hline & & $\begin{array}{c}\text { LMG } \\
\text { 18379T }^{\mathrm{T}}\end{array}$ & $\begin{array}{l}\text { LMG } \\
13019\end{array}$ & $\begin{array}{c}\text { LMG } \\
\text { 18106 }^{\mathrm{T}}\end{array}$ & $\begin{array}{c}\text { LMG } \\
18087^{\mathrm{T}}\end{array}$ & $R-4805$ & $\begin{array}{c}\text { LMG } \\
16407^{\mathrm{T}}\end{array}$ & $\mathrm{R}-4527$ & $\begin{array}{c}\text { LMG } \\
\text { 18819 }^{\mathrm{T}}\end{array}$ & $R-2456$ \\
\hline \multicolumn{11}{|c|}{ P. norimbergensis } \\
\hline LMG $18379^{\mathrm{T}}$ & $63 \cdot 2$ & 100 & & & & & & & & \\
\hline LMG 13019 & $62 \cdot 9$ & 100 & 100 & & & & & & & \\
\hline \multicolumn{11}{|l|}{ P. pulmonicola } \\
\hline LMG $18106^{\mathrm{T}}$ & $61 \cdot 8$ & 44 & & 100 & & & & & & \\
\hline \multicolumn{11}{|l|}{ P. pnomenusa } \\
\hline LMG $18087^{\mathrm{T}}$ & $64 \cdot 3$ & 44 & & 42 & 100 & & & & & \\
\hline R-4805 & $63 \cdot 0$ & & & & 89 & 100 & & & & \\
\hline \multicolumn{11}{|l|}{ P. apista } \\
\hline LMG $16407^{\mathrm{T} *}$ & $61 \cdot 8$ & 32 & 33 & 39 & 37 & 34 & 100 & & & \\
\hline $\mathrm{R}-4527 \dagger$ & $61 \cdot 2$ & & & 35 & 41 & & 95 & 100 & & \\
\hline \multicolumn{11}{|l|}{ P. sputorum } \\
\hline LMG $18819^{\mathrm{T}}$ & $61 \cdot 9$ & 35 & & 39 & 45 & & 40 & 33 & 100 & \\
\hline R-2456 & $61 \cdot 8$ & 34 & 33 & & & & 36 & & 88 & 100 \\
\hline
\end{tabular}

* Protein electrophoretic cluster F.

$\dagger$ Protein electrophoretic cluster E.

Table 4. Fatty acid composition of the strains studied

Results are expressed as mean percentages \pm SD. Those fatty acids for which the mean amount for all taxa was less than $1 \%$ are not given.

\begin{tabular}{|c|c|c|c|c|c|c|c|c|c|c|c|}
\hline & $12: 0$ & $\begin{array}{l}12: 0 \\
2-\mathrm{OH}\end{array}$ & $16: 0$ & $\begin{array}{l}17: 0 \\
\text { cyclo }\end{array}$ & $\begin{array}{l}16: 0 \\
2-O H\end{array}$ & $\begin{array}{l}16: 0 \\
3-\mathrm{OH}\end{array}$ & $\begin{array}{c}19: 0 \\
\text { cyclo } \omega 8 c\end{array}$ & $\begin{array}{l}18: 1 \\
2-O H\end{array}$ & $\begin{array}{l}\text { Summed } \\
\text { feature } 3^{*}\end{array}$ & $\begin{array}{c}\text { Summed } \\
\text { feature } 4 \dagger\end{array}$ & $\begin{array}{l}\text { Summed } \\
\text { feature } 7 \ddagger\end{array}$ \\
\hline P. norimbergensis $(n=4)$ & $3 \cdot 2 \pm 0 \cdot 3$ & $1 \cdot 1 \pm 0 \cdot 2$ & $24 \cdot 8 \pm 0 \cdot 8$ & $19 \cdot 8 \pm 2 \cdot 6$ & $1 \cdot 0 \pm 0 \cdot 1$ & $6 \cdot 1 \pm 0 \cdot 3$ & $14 \cdot 9 \pm 4 \cdot 8$ & $\operatorname{tr}$ & $8 \cdot 2 \pm 0 \cdot 6$ & $6 \cdot 3 \pm 2 \cdot 6$ & $11 \cdot 2 \pm 3 \cdot 9$ \\
\hline P. pulmonicola $(n=3)$ & $2 \cdot 5 \pm 0 \cdot 1$ & $1 \cdot 8 \pm 0 \cdot 1$ & $26 \cdot 9 \pm 0 \cdot 4$ & $17 \cdot 7 \pm 0 \cdot 3$ & $2 \cdot 4 \pm 0 \cdot 2$ & $7 \cdot 5 \pm 0 \cdot 3$ & $17 \cdot 8 \pm 1 \cdot 2$ & $\operatorname{tr}$ & $8 \cdot 9 \pm 0 \cdot 1$ & $4 \cdot 1 \pm 0 \cdot 4$ & $6 \cdot 5 \pm 0 \cdot 8$ \\
\hline P. pnomenusa $(n=6)$ & $1 \cdot 5 \pm 0 \cdot 1$ & $2 \cdot 2 \pm 0 \cdot 2$ & $22 \cdot 8 \pm 1 \cdot 3$ & $13 \cdot 0 \pm 2 \cdot 1$ & $1 \cdot 7 \pm 0 \cdot 4$ & $8 \cdot 0 \pm 1 \cdot 5$ & $9 \cdot 1 \pm 2 \cdot 2$ & $3 \cdot 2 \pm 0 \cdot 7$ & $8 \cdot 9 \pm 1 \cdot 0$ & $7 \cdot 6 \pm 2 \cdot 0$ & $17 \cdot 2 \pm 2 \cdot 5$ \\
\hline P. apista $(n=11)$ & $1.7 \pm 0.6$ & $2 \cdot 4 \pm 0 \cdot 4$ & $23 \cdot 0 \pm 3 \cdot 2$ & $16 \cdot 2 \pm 1 \cdot 8$ & $1 \cdot 3 \pm 0 \cdot 4$ & $7 \cdot 0 \pm 0 \cdot 7$ & $11 \cdot 0 \pm 4 \cdot 7$ & $2 \cdot 0 \pm 0 \cdot 6$ & $8 \cdot 5 \pm 1 \cdot 2$ & $7 \cdot 5 \pm 3 \cdot 2$ & $15 \cdot 4 \pm 4 \cdot 7$ \\
\hline P. sputorum $(n=7)$ & $2 \cdot 0 \pm 0 \cdot 4$ & $2 \cdot 2 \pm 0 \cdot 3$ & $26 \cdot 8 \pm 1 \cdot 4$ & $15 \cdot 8 \pm 2 \cdot 3$ & $1 \cdot 1 \pm 0.5$ & $5 \cdot 8 \pm 0.4$ & $9 \cdot 6 \pm 2 \cdot 1$ & $\operatorname{tr}$ & $7 \cdot 5 \pm 0 \cdot 7$ & $6 \cdot 6 \pm 1 \cdot 3$ & $17 \cdot 4 \pm 3 \cdot 9$ \\
\hline Pandoraea sp. R-5199 $(n=1)$ & $4 \cdot 0$ & $\mathrm{ND}$ & $20 \cdot 76$ & $14 \cdot 43$ & 1.66 & $4 \cdot 57$ & 13.74 & $1 \cdot 11$ & $6 \cdot 75$ & 11.06 & $18 \cdot 45$ \\
\hline
\end{tabular}

ND, Not detected.

tr; trace amount (less than $1 \%$ ).

* Summed feature 3 comprises 14:0 3-OH, 16:1 iso I, an unidentified fatty acid with equivalent chain length value of 10.928, or 12:0 ALDE, or any combination of these fatty acids.

$\dagger$ Summed feature 4 comprises $16: 1 \omega 7 c$ or 15 iso $2-\mathrm{OH}$ or both.

$\$$ Summed feature 7 comprises $18: 1 \omega 7 c, 18: 1 \omega 9 t$, or $18: 1 \omega 12 t$, or any combination of these fatty acids.

of the protein profiles is necessary to avoid misidentification.

Studies have shown that AFLP fingerprinting allowed species level identification of strains belonging to the genera Xanthomonas (Janssen et al., 1996), Aeromonas (Janssen et al., 1996; Huys et al., 1996), Acinetobacter (Janssen et al., 1997), Ralstonia (Coenye et al., 1999a) and Burkholderia (Coenye et al., 1999b) and that the results obtained were generally consistent with DNADNA hybridization levels. In the present study, all
Pandoraea species could easily be distinguished by AFLP fingerprinting (Fig. 3) and the results were in agreement with those obtained by DNA-DNA hybridization (Table 3).

\section{Description of Pandoraea gen. nov.}

Pandoraea (Pan.do.rae'a. N.L. fem. n. Pandoraea referring to Pandora's box in Greek mythology, which was the origin of diseases of mankind, and thus to the surprisingly diverse members of this genus). 
Cells are Gram-negative, non-sporulating, straight rods of $0.5-0.7$ by $1.5-4.0 \mu \mathrm{m}$. They occur singly and are motile by means of a single polar flagellum. Catalase activity is present. Growth is observed at 30 and $37^{\circ} \mathrm{C}$. Nitrite is not reduced. No denitrification. No $\beta$-galactosidase or DNase activity. No liquefaction of gelatin. No aesculin hydrolysis. No indole production. No hydrolysis of Tween 80. Additional characteristics are listed in the Results section above. The following fatty acid components are present: 12:0, 12:0 2-OH, 16:0, 17:0 cyclo, 16:0 2-OH, 16:0 3$\mathrm{OH}, 19: 0$ cyclo $\omega 8 c, 18: 12-\mathrm{OH}$, summed feature 3 , summed feature 4 and summed feature 7 . The $\mathrm{G}+\mathrm{C}$ content is between 61.2 and $64.3 \mathrm{~mol} \%$. Isolated from human clinical samples (mostly CF patients) and the environment. Does not cause soft-rot on onions. The clinical data that are presently available indicate that at least some of these organisms may cause chronic infection in, and have been transmitted amongst, CF patients. The type species is Pandoraea apista sp. nov.

\section{Description of Pandoraea apista sp. nov.}

Pandoraea apista (a.pis'ta. Gr. adj. apistos disloyal, unfaithful, treacherous, referring to the adverse effects of infection for patients).

The description of $P$. apista is the same as that for the genus. Other characteristics are: no growth in $\mathrm{O} / \mathrm{F}$ medium with glucose or on acetamide; no fluorescence on King's B medium; no nitrate reduction; no assimilation of maltose or sucrose; urease, $\mathrm{C}_{8}$-ester lipase, phosphoamidase, amylase and arginine dihydrolase activity present; growth on cetrimide agar; assimilation of citrate, DL-lactate and caprate. The major fatty acids present are 16:0, 17:0 cyclo, 19:0 cyclo $\omega 8 c$ and summed feature 7 . The $\mathrm{G}+\mathrm{C}$ content is between 61.2 and $61.8 \mathrm{~mol} \%$. Isolated from sputum of CF patients. The type strain is LMG $16407^{\mathrm{T}}$ $\left(=\mathrm{CCUG} 38412^{\mathrm{T}}\right)$, isolated from sputum of a $\mathrm{CF}$ patient in Denmark. The description of the type strain is the same as that given above for the species. Its $\mathrm{G}+\mathrm{C}$ content is $61.8 \mathrm{~mol} \%$ and the GenBank accession number for its $16 \mathrm{~S}$ rDNA sequence is AF139173.

\section{Emended description of Pandoraea norimbergensis (Wittke et al. 1997) comb. nov.}

Pandoraea norimbergensis [no.rim.ber.gen'sis. M.L. Norimberga Nürnberg (Bavaria, Germany); M.L. fem. adj. norimbergensis coming from Nürnberg, referring to its place of isolation].

The original description of $P$. norimbergensis was based on data for one strain only. In the present study, we identified three additional isolates as the same species. An emended description of $P$. norimbergensis is given below.

The description of $P$. norimbergensis is the same as that for the genus. Additional characteristics are: no growth at $42{ }^{\circ} \mathrm{C}$; no fluorescence on King's B medium; no nitrate reduction; no growth on acetamide or in $4.5 \% \mathrm{NaCl}$; no assimilation of maltose, adipate or sucrose; no cysteine arylamidase activity present; assimilation of citrate; phosphoamidase activity present; urease activity is strain-dependent. The major fatty acids present are 16:0, 17:0 cyclo, 19:0 cyclo $\omega 8 c$ and summed feature 7 . Isolated from the environment and human clinical samples. The type strain is $\mathrm{LMG}$ $18379^{\mathrm{T}}\left(=\right.$ CCUG $\left.39188^{\mathrm{T}}\right)$. Phenotypic characteristics are the same as described above for the species. In addition, the type strain assimilates D-glucose, arginine dihydrolase activity is present and urease activity is not present. Its $\mathrm{G}+\mathrm{C}$ content is $63.2 \mathrm{~mol} \%$ and the GenBank accession number of its $16 \mathrm{~S}$ rDNA sequence is Y09879. Strain LMG $18379^{\mathrm{T}}$ was isolated from an oxic water layer above a sulfide-containing sediment in Nürnberg (Germany). Other strains have been isolated from human clinical samples and powdered milk. The GenBank accession number for the $16 \mathrm{~S}$ rDNA sequence of strain LMG 13019 (=CCUG 38411) is AF139171.

\section{Description of Pandoraea pulmonicola sp. nov.}

Pandoraea pulmonicola (pul.mo.ni'co.la. L. n. pulmo lung; L. suf. cola dwelling, occurring in; N.L. n. pulmonicola occurring in lungs).

The description of $P$. pulmonicola is the same as that for the genus. Additional characteristics are: no growth on acetamide, or in 3.0 or $4.5 \% \mathrm{NaCl}$; no fluorescence on King's B medium; no assimilation of maltose, adipate or sucrose; no nitrate reduction; no amylase, urease, arginine dihydrolase, $\mathrm{C}_{4}$-esterase, $\mathrm{C}_{8}$ ester lipase or cysteine arylamidase activity present; growth at $42{ }^{\circ} \mathrm{C}$; growth in $\mathrm{O} / \mathrm{F}$ medium with glucose and on cetrimide agar; assimilation of caprate, citrate, DL-lactate and D-glucose; oxidase and phosphoamidase activity present. The major fatty acids are 16:0, 17:0 cyclo, 19:0 cyclo $\omega 8 c$ and summed feature 3 . Isolated from sputum of $\mathrm{CF}$ patients. The type strain is $\mathrm{LMG} 18106^{\mathrm{T}}$ (= CCUG $\left.38759^{\mathrm{T}}\right)$, isolated from sputum of a $\mathrm{CF}$ patient in Canada. The description of the type strain is the same as that given above for the species. Its $\mathrm{G}+\mathrm{C}$ content is $61.8 \mathrm{~mol} \%$ and the GenBank accession number for its $16 \mathrm{~S}$ rDNA sequence is AF139175.

\section{Description of Pandoraea pnomenusa sp. nov.}

Pandoraea pnomenusa [pno.me.nu'sa. Gr. n. pnoe breath, breathing; Gr. v. meno to reside, stay, live (fem. part. pres. menusa); N.L. part. adj. pnomenusa referring to the lung as the niche of these bacteria].

The description of $P$. pnomenusa is the same as that for the genus. Additional characteristics are: no growth in $\mathrm{O} / \mathrm{F}$ medium with D-glucose; no fluorescence on King's B medium; no assimilation of D-glucose, maltose, sucrose or adipate; growth at $42^{\circ} \mathrm{C}$; as- 
Table 5. Characteristics useful for the differentiation of Pandoraea species from R. pickettii, R. paucula and members of the $B$. cepacia complex

Data for R. pickettii, R. paucula and members of the B. cepacia complex were available from previous studies (Vandamme et al., 1999; E. Falsen, unpublished data).

\begin{tabular}{|c|c|c|c|c|c|c|c|c|}
\hline \multirow[t]{2}{*}{ Character } & \multirow{2}{*}{$\begin{array}{c}\text { Pandoraea } \\
\text { Species } \\
(n=32)\end{array}$} & \multirow{2}{*}{$\begin{array}{l}\text { R. pickettii } \\
\quad(n=23)\end{array}$} & \multirow{2}{*}{$\begin{array}{l}R . p a u c u l a \\
\quad(n=7)\end{array}$} & \multicolumn{3}{|c|}{ B. cepacia genomovar } & \multirow{2}{*}{$\begin{array}{l}\text { B. multivorans } \\
(n=6)\end{array}$} & \multirow{2}{*}{$\begin{array}{c}\text { B. vietnamiensis } \\
(n=7)\end{array}$} \\
\hline & & & & $\begin{array}{c}\text { I } \\
(n=14)\end{array}$ & $\begin{array}{c}\text { III } \\
(n=5)\end{array}$ & $\begin{array}{c}\text { IV } \\
(n=2)\end{array}$ & & \\
\hline Catalase activity & + & - & + & - & + & - & - & - \\
\hline $\begin{array}{l}\text { Hydrolysis of } \\
\text { Tween } 80\end{array}$ & - & + & + & + & + & + & + & + \\
\hline $\begin{array}{l}\text { Lysine decarboxylase } \\
\text { activity }\end{array}$ & - & - & - & + & - & + & - & + \\
\hline Nitrite reduction & - & + & - & - & - & - & - & - \\
\hline Denitrification & - & + & - & - & - & - & - & - \\
\hline Gelatin liquefaction & - & - & - & + & + & + & - & - \\
\hline Aesculin hydrolysis & - & - & - & + & - & - & - & - \\
\hline $\begin{array}{l}\beta \text {-Galactosidase } \\
\text { activity }\end{array}$ & - & - & - & + & + & - & + & + \\
\hline \multicolumn{9}{|l|}{ Assimilation of: } \\
\hline Trehalose & - & - & - & + & + & - & + & + \\
\hline L-Arginine & - & - & - & + & + & + & + & + \\
\hline L-Arabinose & - & + & - & + & + & - & + & + \\
\hline Phenylacetate & + & - & + & + & + & + & + & + \\
\hline $\begin{array}{l}\text { Alkaline phosphatase } \\
\text { activity }\end{array}$ & + & - & + & + & + & + & + & + \\
\hline $\begin{array}{l}N \text {-Acetyl- } \beta \text { - } \\
\text { glucosidase } \\
\text { activity }\end{array}$ & - & - & - & + & + & - & - & - \\
\hline$\beta$-Glucosidase activity & - & - & - & + & + & - & - & - \\
\hline
\end{tabular}

similation of caprate, citrate and DL-lactate; urease activity present. The major fatty acids present are 16:0, 17:0 cyclo and summed feature 7. Isolated from sputum of CF patients. The type strain is LMG $18087^{\mathrm{T}}$ $\left(=\right.$ CCUG $\left.38742^{\mathrm{T}}\right)$, isolated from sputum of a $\mathrm{CF}$ patient in Edinburgh, UK. The description of the type strain is the same as that given above for the species. Its $\mathrm{G}+\mathrm{C}$ content is $64.3 \mathrm{~mol} \%$ and the GenBank accession number for its $16 \mathrm{~S}$ rDNA sequence is AF139174.

\section{Description of Pandoraea sputorum sp. nov.}

Pandoraea sputorum (spu.to'.rum. L.n. sputum spit, sputum; L. gen. pl. n. sputorum of sputa).

The description of P. sputorum is the same as that for the genus. Additional characteristics are: no growth in $\mathrm{O} / \mathrm{F}$ medium with glucose or on acetamide; no assimilation of sucrose; no arginine dihydrolase activity present; $\mathrm{C}_{8}$-ester lipase and phosphoamidase activity present. The major fatty acids present are 16:0, 17:0 cyclo, 19:0 cyclo $\omega 8 c$ and summed feature 7. Isolated from sputum of $\mathrm{CF}$ patients. The type strain is LMG $18819^{\mathrm{T}}\left(=\mathrm{CCUG} 39682^{\mathrm{T}}\right)$, isolated from a $\mathrm{CF}$ patient in the USA. Phenotypic characteristics are the same as described above for the species. In addition, the type strain reduces nitrate, produces fluoresence on King's B medium and assimilates maltose and DL-lactate. Its $\mathrm{G}+\mathrm{C}$ content is $61.9 \mathrm{~mol} \%$ and the GenBank accession number for its 16S rDNA sequence is AF139176.

\section{Taxonomic position of strain R-5199}

Strain R-5199 was isolated from garden soil by Parsons et al. (1988) and received special attention due to its ability to utilize biphenyl, 2-chlorobiphenyl, 3-chlorobiphenyl, 4-chlorobiphenyl, $m$-toluate, $p$-toluate, naphthalene, $m$-hydroxybenzoate and diphenylmethane, and due to its ability to transfer chromosomal DNA fragments encoding these characteristics to other strains (Springael et al., 1996). Based on the 16S rDNA sequence, this strain clearly belongs to the genus Pandoraea (Fig. 4). However, SDS-PAGE of whole-cell proteins, AFLP fingerprinting and biochemical data show that this strain does not belong to one of the five described species. At this time, we do not propose a formal name for this strain, pending the availability of similar isolates. 


\section{Differentiation of members of the genus Pandoraea from $R$. pickettii, $R$. paucula and the B. cepacia complex}

In the routine diagnostic laboratory, strains belonging to the genus Pandoraea have been misidentified as $R$. pickettii, $R$. paucula or B. cepacia. Using fatty acid analysis, members of the genus Pandoraea can easily be distinguished from both Ralstonia and Burkholderia species by the absence of 14:0 (Vandamme et al., 1997; Coenye et al., 1999a). Furthermore, compared to Ralstonia species, Pandoraea species have higher percentages of 16:0 3-OH (Coenye et al., 1999a), and differentiation from Burkholderia species is possible due to the presence of significant percentages of 12:0 in Pandoraea species, whilst this fatty acid has not been detected in Burkholderia species (Vandamme et al., 1997). The $\mathrm{G}+\mathrm{C}$ content of strains from the genus Pandoraea $(61.2-64.3 \mathrm{~mol} \%)$ is lower than that of Ralstonia species (64-69\%; Vandamme et al., 1999) and that of members of the B. cepacia complex (67-69\%; Vandamme et al., 1997). Biochemical characteristics useful for differentiation of Pandoraea species from $R$. pickettii, $R$. paucula and members of the $B$. cepacia complex are given in Table 5. In addition, Pandoraea strains can be distinguished from phenotypically similar taxa by SDS-PAGE of wholecell proteins, AFLP fingerprinting and 16S rDNA sequence determinations.

\section{ACKNOWLEDGEMENTS}

T.C. acknowledges the support received from the Vlaams Instituut voor Bevordering van Wetenschappelijktechnologisch onderzoek in de Industrie, Belgium, in the form of a bursary for advanced study. P.V. and M.G. are indebted to the Fund for Scientific Research-Flanders, Belgium, for a position as a postdoctoral fellow, and for research and personnel grants, respectively. We acknowledge the financial support received from the Cystic Fibrosis Trust, UK (grant RS15). We wish to thank Dirk Dewettinck, Liesbeth Lebbe, Cindy Snauwaert, Urbain Torck and Katrien Vandemeulebroecke for excellent technical assistance, and all depositors of strains listed in Table 1. We are indebted to $\mathrm{H}$. Trüper for helpful comments on nomenclatural issues.

\section{REFERENCES}

Coenye, T., Falsen, E., Vancanneyt, M., Hoste, B., Govan, J. R. W., Kersters, K. \& Vandamme, P. (1999a). Classification of some Alcaligenes faecalis-like isolates from the environment and human clinical samples as Ralstonia gilardii sp. nov. Int J Syst Bacteriol 49, 405-413.

Coenye, T., Schouls, L. M., Govan, J. R. W., Kersters, K. \& Vandamme, P. (1999b). Identification of Burkholderia species and genomovars from cystic fibrosis patients by AFLP fingerprinting. Int J Syst Bacteriol 49, 1657-1666.

Costas, M. (1992). Classification, identification, and typing of bacteria by the analysis of their one-dimensional polyacrylamide gel electrophoretic protein patterns. In Advances in Electrophoresis, vol. 5, pp. 351-408. Edited by A. Chambrach, M. J. Dunn \& B. J. Radola. Weinheim: VCH.

Ezaki, T., Hashimoto, Y. \& Yabuuchi, E. (1989). Fluorometric deoxyribonucleic acid-deoxyribonucleic acid hybridisation in microdilution wells as an alternative to membrane filter hybridisation in which radioisotopes are used to determine genetic relatedness among bacterial strains. Int $J$ Syst Bacteriol 39, 224-229.

Gilligan, P. H. (1991). Microbiology of airway disease in patients with cystic fibrosis. Clin Microbiol Rev 4, 35-51.

Gonzalez, C. F. \& Vidaver, A. K. (1979). Bacteriocin, plasmid and pectolytic diversity in Pseudomonas cepacia of clinical and plant origin. J Gen Microbiol 110, 161-170.

Goris, J., Suzuki, K., De Vos, P., Nakase, T. \& Kersters, K. (1998). Evaluation of a microplate DNA-DNA hybridization method compared with the initial renaturation method. Can J Microbiol 44, 1148-1153.

Govan, J. R. W. \& Deretic, V. (1996). Microbial pathogenesis in cystic fibrosis: mucoid Pseudomonas aeruginosa and Burkholderia cepacia. Microbiol Rev 60, 539-574.

Huys, G., Coopman, R., Janssen, P. \& Kersters, K. (1996). Highresolution genotypic analysis of the genus Aeromonas by AFLPfingerprinting. Int J Syst Bacteriol 46, 572-580.

Janssen, P., Coopman, R., Huys, G., Swings, J., Bleeker, M., Vos, P., Zabeau, M. \& Kersters, K. (1996). Evaluation of the DNA fingerprinting method AFLP as a new tool in bacterial taxonomy. Microbiology 142, 1881-1893.

Janssen, P., Maquelin, K., Coopman, R., Tjernberg, I., Bouvet, P., Kersters, K. \& Dijkshoorn, L. (1997). Discrimination of Acinetobacter genomic species by AFLP fingerprinting. Int $J$ Syst Bacteriol 47, 1179-1187.

LiPuma, J. J. (1998). Burkholderia cepacia. Management issues and new insights. Clin Chest Med 19, 473-486.

Mesbah, M., Premachandran, U. \& Whitman, W. B. (1989). Precise measurement of the $\mathrm{G}+\mathrm{C}$ content of deoxyribonucleic acid by high-performance liquid chromatography. Int $J$ Syst Bacteriol 39, 159-167.

Parsons, J. R., Sijm, D. T. H., van Laar, A. \& Hutzinger, O. (1988). Biodegradation of chlorinated biphenyls and benzoic acids by a Pseudomonas strain. Appl Microbiol Biotechnol 29, 81-84.

Pitcher, D. G., Saunders, N. A. \& Owen, R. J. (1989). Rapid extraction of bacterial genomic DNA with guanidium thiocyanate. Lett Appl Microbiol 8, 109-114.

Pot, B., Vandamme, P. \& Kersters, K. (1994). Analysis of electrophoretic whole-organism protein fingerprints. In Chemical Methods in Prokaryotic Systematics, pp. 493-521. Edited by M. Goodfellow \& A. G. O'Donnell. Chichester: Wiley.

Saitou, N. \& Nei, M. (1987). The neighbor-joining method: a new method for reconstructing phylogenetic trees. Mol Biol Evol 4, 406-425.

Springael, D., van Thor, J., Goorissen, H. \& 7 other authors (1996). RP4::Mu3A-mediated in vivo cloning and transfer of a chlorobiphenyl catabolic pathway. Microbiology 142, 3283-3293.

Stackebrandt, E. \& Goebel, B. M. (1994). Taxonomic note: a place for DNA-DNA reassociation and 16S rRNA sequence analysis in the present species definition in bacteriology. Int $J$ Syst Bacteriol 44, 846-849.

Vandamme, P., Vancanneyt, M., Pot, B. \& 10 other authors (1992). Polyphasic taxonomic study of the emended genus Arcobacter with Arcobacter butzleri comb. nov. and Arcobacter skirrowii sp. nov., an aerotolerant bacterium isolated from veterinary specimens. Int J Syst Bacteriol 42, 344-356.

Vandamme, P., Gillis, M., Vancanneyt, M., Hoste, B., Kersters, K. \& Falsen, E. (1993). Moraxella lincolnii sp. nov., isolated from the 
human respiratory tract, and re-evaluation of the taxonomic position of Moraxella osloensis. Int J Syst Bacteriol 43, 474-481.

Vandamme, P., Holmes, B., Vancanneyt, M. \& 8 other authors (1997). Occurrence of multiple genomovars of Burkholderia cepacia in cystic fibrosis patients and proposal of Burkholderia multivorans sp. nov. Int J Syst Bacteriol 47, 1188-1200.

Vandamme, P., Goris, J., Coenye, T., Hoste, B., Janssens, D.,
Kersters, K., De Vos, P. \& Falsen, E. (1999). Assignment of Centers for Disease Control group IVc-2 to the genus Ralstonia as Ralstonia paucula sp. nov. Int J Syst Bacteriol 49, 663-669.

Wittke, R., Ludwig, W., Peiffer, S. \& Kleiner, D. (1997). Isolation and characterisation of Burkholderia norimbergensis sp. nov., a mildly alkaliphilic sulfur oxidizer. Syst Appl Microbiol 20, 549-553. 